\title{
Molecular Mechanisms in Plant Abiotic Stress Response
}

\author{
Palmiro Poltronieri - Stefania Bonsegna $\cdot$ Stefania De Domenico $\cdot$ Angelo Santino
}

received / primljeno: 15.04.2010. revised / prerađeno: 02.12.2010. accepted / prihvaćeno: 15.12.2010. (C) 2011 IFVC

\begin{abstract}
Summary: Improved crop varieties are needed to sustain the food supply, to fight climate changes, water scarcity, temperature increase and a high variability of rainfalls. Variability of drought and increase in soil salinity have negative effects on plant growth and abiotic stresses seriously threaten sustainable agricultural production. To overcome the influence of abiotic stresses, new tolerant plant varieties and breeding techniques using assisted selection are sought. A deep understanding of the mechanisms that respond to stress and sustain stress resistance is required. Here is presented an overview of several mechanisms that interact in the stress response. Localised synthesis of plant hormones, second messengers and local effectors of abiotic stress response and survival, the signalling pathways regulated by plant hormones are today better understood. Metabolic networks in drought stress responses, long distance signalling, cross-talk between plant organs finalised to tissue-specific expression of abiotic stress relieving genes have been at the centre of most recent studies.
\end{abstract}

Key words: abscisic acid (ABA), jasmonate (JA), osmotic adjustment (OA), transcription factor (TF)

\section{Introduction}

Modern agriculture faces abiotic stresses, especially salinity and drought as major factors limiting crop productivity worldwide. Low temperatures, heath shock, heavy metals, UVradiation and pesticides are also abiotic factors affecting crop yields (Bohnert et al. 1995, Tardieu \& Tuberosa 2010). Climate changes with erratic rainfalls and prolonged drought out of the expected season have multiplicative effects on abiotic stress consequences and seriously threaten sustainable agricultural production. High salinity is not only a soil-type characteristic but can be also observed in arable, irrigated areas due to use of low quality water. In addition, soil salinity induces water deficit that leads to nutrient deficiencies. Abiotic stress is one primary cause of crop loss worldwide, causing average yield losses of more than $50 \%$ for major crops. Plants can resist abiotic stresses through different distinct mechanisms. Tolerance and susceptibility to abiotic stresses are very complex. Plant traits that are associated with resistance mechanisms are multigenic and thus difficult to control and engineer.

P. Poltronieri $(\bowtie) \cdot S$. Bonsegna $\cdot$ S. De Domenico $\cdot$ A. Santino ISPA-CNR, Institute of Sciences of Food Productions, Via Monteroni 73100 Lecce, Italy

e-mail: palmiro.poltronieri@ispa.cnr.it
Drought induces mechanical stress on roots due to soil hardness, osmotic stress because of cell dehydration and removal of water in the extra-cellular space, and oxidative stress by the accumulation of reactive oxygen species (ROS) (Kovtun et al. 2000).

Plants respond to water stress through organcompartmentalised changes. In roots, there is an enhanced capture of soil moisture (e.g. reaching deep soil moisture with longer roots), while in stem/leaves there is a reduction of water loss (e.g. stomatal closure, reduction of plant size and/or leaf area) retaining tissue hydration via osmotic adjustments (OA). A prolific and deep root system confers better growth and yield under terminal drought, especially for varieties showing either deep rooting features and a positive harvest index (number and size of seeds) (Chandra Babu et al. 2001). In the case of water scarcity or drought, plants improve their water use efficiency either by dehydration avoidance or through dehydration tolerance (Plaut et al. 2004, Thomas \& Howarth 2000, Blum 2005).

Reduced growth duration (with early flowering) is also an important mechanism as the plant generally uses less water and can also avoid the end-of-season (terminal) stress. However, reduced or early flowering plants may lead to lower production rates and smaller seeds. 


\section{Stress-Responsive Gene Expression}

Under abiotic stress (drought, salinity) plants respond with the activation of synthesis or inhibition of catabolism of osmolytes as sugars (saccharopine, trehalose, raffinose, galactinol, sorbitol, mannitol, fructans) (Cortina \& Culianez-Macia 2005) and sugar alcohols (e.g. polyols), amino acids as branched chain aminoacids (BCA), proline and agmatin, quaternary ammonium compounds and small dipeptides as glycinebetaine (Holmstrom et al. 2000). Polyamines (i.e. putrescine) are involved in a wide range of plant processes including wounding (Groppa \& Benavides 2008). Having a role in development and $\mathrm{H}_{2} \mathrm{O}_{2}$ production, amine oxidases are involved in the increase of polyamines that mediate the stress responses.

There is a need to provide established or new varieties with genotypes having enhanced or faster induction of expression of genes at the crossroad of permissive growth under stress condition. This group of permissive genes includes aquaporin isoforms able to optimise water fluxes (Javot et al. 2003). Several genes have been characterised for their role on stress protection. ERECTA is a gene regulating transpiration efficiency affecting stomatal closure, while the plant is able to maintain biomass production (Masle et al. 2005).

Other important regulatory proteins involved in drought stress are proton antiporters as TNHX1 and a proton pyrophosphatase TVP1 (Brini et al. 2005, Brini et al. 2007a) shown to improve salt and drought stress tolerance in Arabidopsis.

Dehydrin isoforms (LEA/DHN) of sizes 17 $\mathrm{kDa}, 30 \mathrm{kDa}$ and $40 \mathrm{kDa}$, function as intracellular chaperones for other proteins and nucleic acids. One dehydrin (DHN-5) was shown to be involved in salt and drought resistant phenotypes of durum wheat (Brini et al. 2007b). Dehydrins accumulate to a high level in the mature embryos. The accumulation of DHN- 5 was shown to have a role in preservation of cell integrity during late embryogenesis and desiccation (Brini et al. 2007b). Dehydrins are also known as late embryogenesis abundant (LEA) or early response to dehydration (ERD) proteins (Beck etal.2007), so called because they also accompany seed formation. It has been shown that LEA/DHNs exert chaperone activity on proteins and also nucleic acids (Kovacs et al. 2008; Hara et al. 2009). DHN/LEAs lack a fixed three-dimensional structure, remarkably stable even at macromolecular crowding conditions, maintaining a disordered character under conditions (dehydration) in which unfolded states of several globular proteins would tend to collapse (Mouillon et al. 2008). Several LEA/ DHN isoforms are regulated by abscisic acid (ABA) Jimenez et al. 2008). While the size of induced DHNs was large, ranging between 14 $\mathrm{kDa}$ and $74 \mathrm{kDa}$, drought-tolerant bermudagrass varieties showed to induce preferentially the 31 $\mathrm{kDa}$ and $40 \mathrm{kDa}$ isoforms (Hu et al. 2010).

Roots grow and recover their function after environmental stresses through specific genes that adapt root development to these restrictive conditions. The recovery of Medicago truncatula roots after a salt stress is mediated by regulatory networks depending on TFIIIA-like transcription factors, involved in the control of root adaptation to salt stress. Those conditions induced synthesis of a novel RNA-binding protein, a small G-protein homologous to ROP9, a receptor-like kinase, two TF IIIA-like and an AP2-like transcription factors (TF), MtZpt2-1, MtZpt2-2 and MtAp2, and a histidine kinase associated with cytokinin transduction pathways (Merchan et al. 2007).

\section{Role of JA and ABA in Stress Signalling}

The interplay of several plant hormones regulates the commitment of plants to growth or senescence under abiotic stress. The plant copes with a specific stress through complex signals circulating from roots to shoots and leaves (Fig. 1), and delivering hormones and signalling back to the roots, activating the expression of protective proteins or down-regulating unnecessary pathways. Plant hormones sustain signals at short distance, between cells, or in a systemic way in the case of transport systems. In this review, we will focus principally on the roles exerted by jasmonic acid (JA) and abscisic acid (ABA). JA is the final product of the octodecanoic pathway which uses linoleic acid as substrate to produce oxylipins (Hughes et al. 2009). The octodecanoic pathway starts with the oxygenation of a polyunsaturated fatty acid (PUFA) by lipoxygenase (LOX), to form a fatty acid hydroperoxide. In plants, only the type-2 13-LOXs are believed to be associated with JA biosynthesis (De Domenico et al. 2007). In the biosynthesis of JA, the subsequent activities of 13-LOX, allene oxide synthase (AOS), allene oxide cyclase (AOC) lead to formation of cis(+)-12-oxophytodienoic acid (OPDA), a JA precursor. JA can be methylated by a specific JA-methyltransferase. Methyl-Jasmonate (MeJA) is a volatile compound able to cross plasma membranes and exert its action at distance. Another effector in the lipoxygenase biosynthesis pathway is jasmonate-conjugated isoleucin (JAIle) that may accumulate stored in organelles and 
vacuoles. JA-Ile is able to translocate through membranes and move through xylem from roots to leaves and backward.

Once the hormone has arrived at its destination in the target cell (locally or at distance), the priming of jasmonate-inducible genes is regulated by convergent pathways, linked to phosphoinositideand ABA-dependent signalling components. nitrogen-fixing bacteria. AM interaction is widely distributed among most of the land plants, while actinorhiza and rhizobia interactions are restricted to species of ten plant families, including the legumes. Fungi of the phylum Glomeromycota exist in a symbiotic association with vascular plants (Schüssler et al. 2006). As for the actinorhiza, the symbiosis occurs between actinobacteria of the

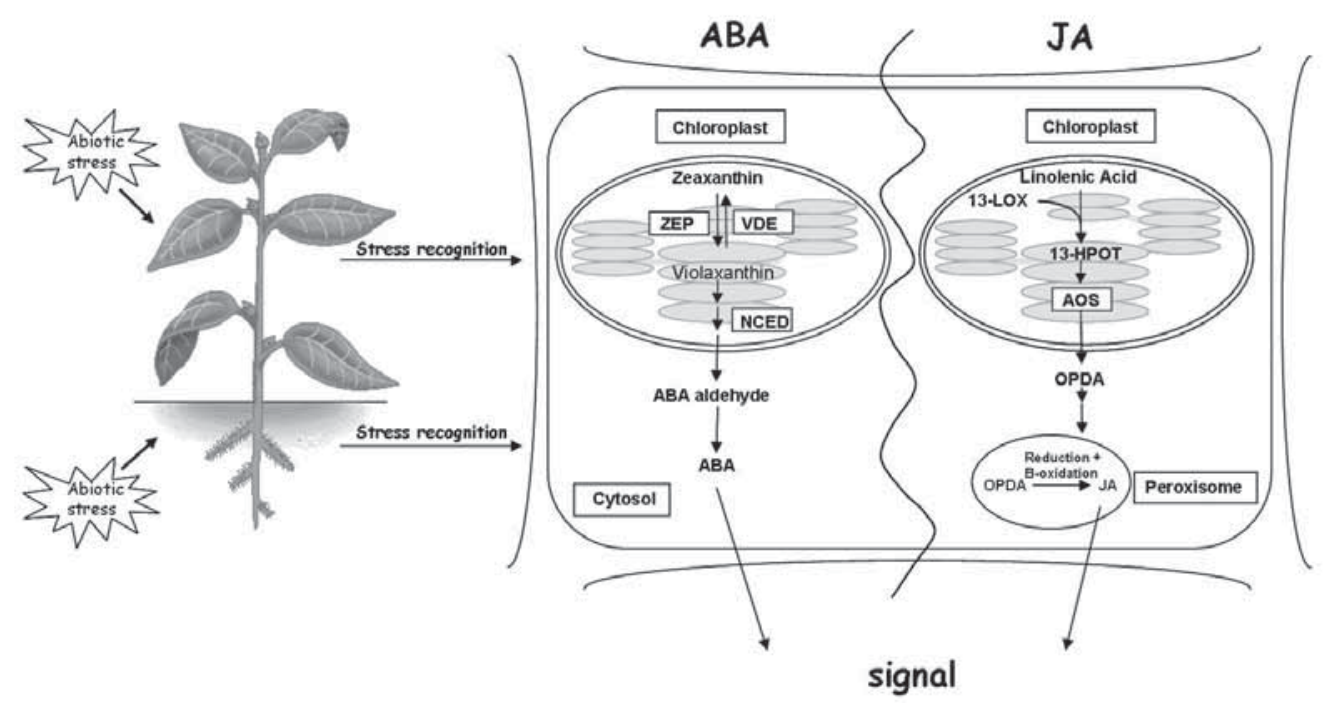

Fig. 1. The ABA and JA biosynthesis pathways in plants

Slika 1. Tokovi biosinteze ABA i JA u biljkama

The ABA synthesis involves multiple reactions that occur in the plastid and the cytoplasm. ZEP: zeaxanthin epoxidase; VDE: violaxanthin de-epoxidase; NCED: 9-cis-epoxycarotenoid di-oxygenase. The final steps in ABA synthesis in the cytosol involves a xanthoxin:NAD+ oxidoreductase (mutated in aba2) and the ABA aldehyde oxidase.

The JA biosynthesis pathway involves two compartments. Chloroplast route: linolenic acid (18:3) is used as substrate for the sequential action of three plastidial enzymes, lipoxygenase (LOX), allene oxide synthase (AOS) and allene oxide cyclise, which produces 12-oxo-phytodienoic acid (OPDA). Peroxisome route: following OPDA import into peroxisomes, jasmonic acid is produced by oxophytodienoate reductase 3 in three cycles of $\beta$-oxidation.

\subsection{JA Signalling in Root Response to Abiotic} Stresses

Plant growth and development are largely dependent on the plant root system, due to its crucial role in water and mineral uptake. Abiotic below-ground stresses (e.g. drought, waterlogging, salt, nutrient soil status, physical soil properties) affect overall plant growth and architecture. This early signalling affects root growth regulation, resource acquisition and rootshoot communication under abiotic stress.

Many plants develop mutualistic interactions with arbuscular mycorrhizal (AM) fungi and with genus Frankia and plants of Fagales, Cucurbitales and Rosales (Pawlowski \& Sirrenberg 2003). On the other hand, the legume-rhizobia symbiosis (LRS) occurs between Rhizobium species and legumes (Kistner \& Parniske 2002). Both types of nodule symbioses are characterized by the intracellular uptake of bacteria and the formation of specialized organs, the root nodules.

A phytohormone involved in the regulation of interactions between root and bacteria is JA and its conjugated form (MeJA) which cross the membrane barrier functioning as a long-distance signal (Hause \& Schaarschmidt 2009). MeJA has been detected in high levels in germinating 
soybeans and in root tips (Mason et al. 1992, Oldroyd 2009). Jasmonates directly induce nod gene expression in rhizobia, and indirectly promote bacterial Nod factor production by inducing (iso)flavonoid biosynthesis genes in the plant (Zhang et al. 2007). As a negative feedback, Nod factor causes $\mathrm{Ca}^{2+}$ spiking in root hairs (Oldroyd 2009).

Regulation of the redistribution of nutrients might be the most important role of jasmonates in AM roots. In plants such as $M$. truncatula and barley, developing a mutualistic symbiosis which ultimately leads to a promoted growth, jasmonates might help to regulate the nutrient exchange between both partners. However, root JA and Me-Ja are important also in plants devoid of symbiotic relationships.

\subsection{JA Receptors and Downstream Signal}

Transduction in Distant Signalling and Abiotic Stress Response

There is an intense communication between different organs through the phloem sap, the system of delivery of nutrients and solutes, and through the xylem, the water channels which move soluble compounds from roots to leaves. How these signals move, using the xylem or the phloem way, upward or downward, and which compounds (conjugated phytohormones, proteins, RNAs) is mostly unknown and under investigation, but several findings show a significant role of certain hormones and signals (Lough \& Lucas 2006).

JA-related compounds have been identified in plants with mutations in components of the ubiquitin proteasome system (Tiryaki \& Staswick 2002, Lorenzo \& Solano 2005, Moon et al. 2007). Recent developments include the identification of COI1 as a receptor for jasmonates. COI1 is an F-box protein taking part of an Skp1-CullinF-box (SCF) complex, closely related to the auxin signalling TIR1 (TRANSPORT INHIBITOR RESPONSE 1) gene, which encodes the first plant F-box protein to be identified as part of an SCF complex. SCF complex interacts with CORONATINE INSENSITIVE1 (COI1) E3 ubiquitin ligase, that targets proteins to the proteasome degradation pathway. COI1 directly binds (+)-7-iso-JA-1-Ile and thus functions as JA receptor revealed that formation of the ternary complex COI1-JA-Ile-JAZ is an ordered process (Balbi and Devoto 2008). JA-Ile promotes the interaction between the ubiquitin ligase complex $\mathrm{SCF}(\mathrm{COI} 1)$ and JAZ proteins, resulting in their degradation by the $26 \mathrm{~S}$ proteasome, thereby liberating AtMYC2 from repression according to the prevailing model.

Two jasmonate-responsive promoter sequences are known. The GCC motif, commonly found in promoters activated synergistically by jasmonate and ethylene, and the G-box, found in promoters activated by jasmonates and repressed by ethylene. Important transcription factors conferring jasmonate-responsive gene expression in Arabidopsis are ORA59 and AtMYC2. ORA59 interacts with the GCC motif and controls the expression of genes that are synergistically induced by jasmonates and ethylene, whereas AtMYC2 interacts with the G-box and related sequences, and controls genes activated by jasmonate alone (Gfeller et al. 2010).

\subsection{Early Stress Sensing in Roots and} Associated Bacteria and Fungi

Once the soil derived signals (mechanical and osmotic stress, and signals originated from the stressed ectomycorrhiza) are sensed by root, they are rapidly translated into specific signals. The relevance of an early and immediate response in stress tolerant varieties is utmost, while in unresponsive varieties there is a delayed and reduced response (Schachtman \& Goodger 2008).

Plant-growth-promoting (PGP) fungi (Pennisi 2006, White \& Torres 2010) and plant-growth-promoting rhizobacteria (PGPR) (Liu et al. 2007) augment plant productivity and immunity through an increase in the antioxidative state. PGP endophytes induce root biomass, counteract salt-induced increase in heat efflux, produce changes in fatty acids composition, reduce lipid peroxidation in leaves, increase antioxidant enzyme activities and enable roots to maintain ascorbate in its reduced state under salt stress (Baltrushat et al. 2008). Certain bacteria promote plant growth through the activity of several genes, coding for putative proteins involved in survival in the rhizosphere (to cope with oxidative stress or uptake of nutrients released by plant roots), root adhesion (pili, adhesion, hemagglutinin, cellulose biosynthesis), colonization/establishment inside the plant (chemiotaxis, flagella, cellobiose phosphorylase), plant protection against fungal and bacterial infections (siderophore production and synthesis of the antimicrobial compounds 4-hydroxybenzoate and 2-phenylethanol), and improved growth and development through the production of the phytohormones indole acetic acid, acetoin, and 2,3-butanediol (Taghavi et al. 2010). 
PGPR also elicit the 'induced systemic tolerance' to salt and drought. Even in the non-ectosymbiotic population of bacteria, there are positive influences on the plant hosts. The Pseudomonas syringae phytotoxin coronatine mimics jasmonoylisoleucine (JA-Ile), which is a crucial plant signalling molecule for regulating plant defence responses (Weiler et al. 1994, Bender et al. 1999). During water stress, the nodules sense drought and respond by activating defence mechanisms (Luo et al. 2009). In this way, Ectomycorrhizas (EMs) and rhizobia alleviate and improve also stress tolerance of host plants (Yang et al. 2009). It is worthy to note that arbuscular mycorrhizal fungi host endosymbiotic bacteria providing beneficial properties such as heat tolerance and protection from pests (Naumann et al. 2010).

Bacteria possess a nitric-oxide-synthase involved in stress resistance. $\mathrm{NO}$ is a mobile gaseous second messenger that is sensed at root level. In legumes, globin NO binding proteins, called leghemoglobins, accumulate in symbiosomes (root nodules) of various legumes. Non-symbiotic $b b$ genes are expressed in specific plant tissues, and over-expressed in organs of stressed plants. These observations suggest that nsHbs function as additional to $\mathrm{O}(2)$-transporters, such as to modulate levels of ATP and NO (avoiding protein nitrosylation). Non-symbiotic haemoglobins are a key enzymatic system for NO scavenging in plants, indicating that the primordial function of haemoglobins may be linked to the protection against nitrosative stress (Perazzolli et al. 2006, Smagghe et al. 2009).

$P$. fuorescens WCS417r bacteria and betaaminobutyric acid can induce disease resistance in Arabidopsis, priming specific defence mechanisms. Both WCS417r and beta-aminobutyric acid prime enhanced deposition of callose-rich papillae after infection by the oomycete Hyaloperonospora arabidopsis (Van der Ent et al. 2009).

\subsection{Abscisic Acid in Abiotic Stresses}

Abscisic acid (ABA) is a phytohormone involved in senescence, seed dormancy, plant development, drought tolerance and stress response, synthesised in the xylem and in the aerial parts of the plant, where it regulates stomatal movement and the activity of shoot meristems. ABA can flow in the root cortex across apoplastic barriers and play an important role in the regulation of signal intensity. The abscisic acid glucose ester (ABA$\mathrm{GE})$ is a long-distance stress signal, stored in microsomes, and released by activated betaglucosidases, both in the apoplast and the cytosol of the mesophyll cells. ABA-GE transporters located on plasma membrane of the xylem parenchyma cells influence ABA mobility. When discussing the intensity of the ABA signal in the xylem, internal and external sources of ABA have to be considered. External ABA originates from root exudation and from ABA-producing soil organisms (predominantly fungi), whereas internal ABA comes from its biosynthesis at root shoots level and phloem import (Sauter \& Hartung 2000, Sauter et al. 2001). It was shown that conjugated ABA (ABA-GE) also occurs in the soil, often in higher concentrations than ABA. The Casparian bands of the exodermis and endodermis are perfect barriers for ABA-GE. When an exodermis is absent (Fabaceae and hydroponically cultivated plants), external ABA-GE enters into the apoplast of the root cortex. Apoplastic $\beta$-glucosidases can cleave the conjugated form and release free $\mathrm{ABA}$, which is distributed to the symplast and/or transported across the endodermis into the xylem (Hartung et al. 2002).

\subsection{Timing of ABA Synthesis and} Mobilisation

$\mathrm{NaCl}$ causes a rapid increase in ABA level in the transpiring portion of growing leaves. Within 10 min following salt addition, ABA levels show a 6 -fold increase in the distal portion of the leaf elongation zone whereas it accumulate later in the proximal portion. In the portion of the growing blade, ABA increases 3-fold and remains elevated during the following $20 \mathrm{~min}$. This precedes the decrease in transpiration and stomatal conductivity. Twenty hours following salt addition, $\mathrm{ABA}$ concentration returned to the pre-stress level. Leaf elongation velocity was still reduced. An ATP-Binding Cassette (ABC) transporter, AtABCG25, expressed mainly in vascular tissues such as roots and leaf veins, localized in the outer cell membranes (Kuromori et al. 2010) was identified as the gene involved in a plant mutant hypersensitive to $\mathrm{ABA}$ at the germination and seedling stages. Plants genetically engineered to over express AtABCG25 had higher leaf temperature compared to normal plants and decreased water loss from isolated leaves. Thus, facilitated ABA movements may affect distant targets such as guard cells.

\subsection{Salt Stress and Phosphate Deficiency} Increase ABA Formation in the Roots

Strong ABA synthesis and accumulation in the roots can be observed in plants affected by 
hemiparasites such as Rhinanthus minor (Jiang et al. 2004). ABA biosynthesis in the roots was 12 -fold higher after attack, resulting in 14-fold higher ABA flows in the xylem.

Plants regulate inorganic phosphate (Pi) homeostasis to adapt to environmental changes in Pi availability. Some degree of cross-talk between $\mathrm{ABA}$ and other signalling pathways was reported in phosphate limitation conditions. This mechanism involves phosphate uptake increase from the soil and phosphate mobilization from the leaf. Upon Pi starvation, upregulated miR399 cleaves its target gene, $\mathrm{PHO} 2$, in $A$. thaliana, an ubiquitinconjugating E2 enzyme, thereby releasing several protein targets from ubiquitin-pathway dependent degradation and increasing $\mathrm{Pi}$ content in the shoots (Franco-Zorrilla et al. 2007).

\subsection{Correlation between Xylem ABA}

Concentration and Leaf Conductance

ABA signalling can be intensified in many crops, for instance grapevine, by applying modern irrigation techniques, such as partial root drying (PRD). PRD is an irrigation technique where water is distributed unevenly to the root system divided into irrigated and dry compartments. Applying PRD to grape cultivation (Stoll et al. 2000), ABA signalling was found to be reduced after prolonged drying of one compartment. To sustain PRD effects, it was necessary to alternate wet and dry parts regularly (PRD-A). PRD-A was shown to intensify ABA signalling with positive consequences for water saving and improvement of the quality of the crops (Dodd et al. 2008). The factors that regulate the intensity of the ABA signal in the xylem, on its route from the root to the target cells, are therefore of particular interest.

\subsection{Role of ABA in JA Signalling}

Recent findings have suggested an interaction between jasmonic acid and ABA in plants under drought stress (Mahouachi et al. 2007). The pattern of accumulation of JA is compatible with a triggering signal upstream ABA. The phytohormone ABA acts in all adaptive responses to environmental stresses. The phytohormones gibberellin (GA) and ABA play essential and often antagonistic roles in regulating plant growth, development and stress responses. The transduction of their signal occurs through several types of receptors (Razem et al. 2006). Soil water stress elicits a hydraulic response in the shoot, which precedes ABA signalling and stomatal closure (Christmann et al. 2007). ABA biosynthesis in leaves is increased significantly only when turgor approaches zero. The location of $\mathrm{ABA}$ release and the tissue-specific expression of $\mathrm{ABA}$ receptor types are signals for that particular tissue (seeds, leaves) to reorganize and reprogram, through epigenetic control, differential gene expression of an ABA-directed cluster of genes (Seki et al. 2007).

\subsection{ABA Receptors and Downstream Signal} Transduction

The Arabidopsis ABA receptor FLOWERING TIME CONTROL LOCUS A (FCA), the GA receptor GIBBERELLIN INSENSITIVE DWARF1 (GID1) and the nuclear-located auxin receptor show an important activity as plant hormone receptors within the cell nucleus. GID1, FCA and TRANSPORT INHIBITOR RESPONSE1 (TIR1) receptors reveal a novel signalling mechanism that appears to be short, to be independent of relay intermediates, and to involve only protein-protein interactions that are affected by receptor-hormone binding.

FCA is a plant-specific RNA-binding protein, possesses two RNA-recognition motifs (RRM) in addition to a tryptophan-tryptophan (WW) protein-interaction domain. FCA shares sequence homology at the C-terminus with the ABA-binding protein (ABAP1) associated with the plasma membranes of barley aleurone cells. FCA ABA receptor affects RNA metabolism by binding directly to an RNA binding protein (Simpson et al. 2003).

Although ABAP1 does not possess the common RRM to bind RNA, it does possess a WW interaction domain that harbours residues homologous to the Prp40 splicing factor and there is substantial evidence to link nuclear WWcontaining proteins to both transcription and RNA splicing. ABA-ABAP1 binding results in changes in ABAP1 protein conformation, the subsequent dissociation from an interacting protein in the plasma membrane, and the appearance of ABAP1 in cytosolic and nuclear compartments. In either instance, if the proteins that interact with characterized (FCA) or putative (ABAP1) receptors are restricted in their subcellular localization, then the mobility of ABA hormone receptors might have particular relevance for covering the entire suite of nongenomic and genomic responses encompassed by ABA (Hugouvieux et al. 2001).

PYR/PYL/RCAR proteins function as ABA receptors that, following $\mathrm{ABA}$ binding, inhibit 
the activity of known negative regulators of $\mathrm{ABA}$ signalling (the type $2 \mathrm{C}$ protein phosphatases (PP2Cs) ABI1, ABI2, HAB1, HAB2 and PP2CA) in both seeds and vegetative tissues. In the presence of ABA, PYR/PYL/RCARs bind to PP2Cs and induce the release of SNRK2 Ser/Thr kinases from PP2Cs, which would otherwise keep SNRK2s in an inactive state. The association of PYR1, ABI1, SRK2E and ABF2 is sufficient for ABA-triggered ABF2 phosphorylation (Fujii et al. 2009). SNRK2s phosphorylation of downstream substrates, including ABA responsive elementbinding protein (AREB) and $\mathrm{ABA}$ responsive element-binding factor (ABF) bZIP transcription factors activates ABA-responsive genes and ABA-related responses (Yin et al. 2009).

Another transcription factors activated by ABA signalling is R2R3MYB that translates ABA effects through differential gene expression (Abuqamar et al. 2009).

GPCR-type G proteins (GTG1 and GTG2) bind $\mathrm{ABA}$ specifically and interact with the Arabidopsis $G$ protein alpha subunit, GPA1, but also have intrinsic GTP-binding and GTPase activity (Pandey et al. 2009).

Epigenetic processes are an integral part of ABA-regulated processes. Epigenetic mechanisms, namely, histone modifications and cytosine DNA methylation-induced modification of genome give rise to epigenomes (Chinnusamy et al. 2008). Abiotic stress-induced ABA regulates stomatal response and stress responsive gene expression through HDACs and HOS15-dependent histone deacetylation, as well as through the ATP dependent SWITCH/SUCROSE NONFERMENTING CRC. ABA also probably regulates the abiotic stress response through DNA methylation and short interfering RNA pathways. Further studies on ABA-regulated epigenome will be of immense use to understand the plant development, stress adaptation and stress memory.

\subsection{ABA and Abiotic Stress Memory}

Abiotic stress-induced genomic changes are necessary for stress memory. UV-C radiation or flagellin (a plant defence elicitor) stress-induced changes in the genome have been shown to be a dominant trait and transmitted through both the maternal and the paternal crossing partner in Arabidopsis (Molinier et al. 2006). Progeny of tobacco mosaic virus (TMV) infected plants showed enhanced frequency of the somatic and meiotic recombination rates at certain loci due to DNA hypomethylation. Thus, stress memory appears to be inherited through epigenetic changes
(Boyko et al. 2007). ABA may be involved also in the somatic recombination frequency (Boyko et al. 2006) and induces chromatin remodelling, which regulates transcription, recombination, replication and genome organization. It is also likely that $\mathrm{ABA}$ might regulate DNA methylation through DML3 and siRNAs. Under abiotic stresses ABA mediates reduction in plant growth. One of the mechanisms of abiotic stressinduced growth arrest is regulated by chromatin remodelling (Mlynarova et al. 2007). Abiotic stress-induced inheritable epigenetic state might have an adaptive advantage but also a negative effect on the yield of crops, as stress memory can inhibit the expression of full potential of crops. There is a great interest to understand the role of $\mathrm{ABA}$ in abiotic stress memory to exploit it in agricultural practices.

2.8 Regulatory Metabolic Networks in Drought Stress Responses

Localised delivery of paracrine hormones, long distance signalling and a second wave of tissue specific hormone signals regulate the intensity of ABA signals (Jiang \& Hartung 2008).

In higher plants, a number of physiological processes are regulated by systemic RNA signalling molecules. This phloem-mediated remote-control system provides specific and efficient regulation to fine-tune many plant developmental programs. In phloem, several endogenous RNA-binding proteins have been identified. In addition, viral RNA-binding proteins can counterbalance the plant RNA silencing effectors synthesised to block viral RNA (Lakatos et al. 2004). CmPP16 protein from Cucurbita maxima was shown to possess properties similar to those of viral movement proteins (Xoconostle-Cázares et al. 1999). Messenger RNAs have been shown to travel at long distance in the phloem. Four mRNAs (BEL5, Le'T6, KNOT'TED1 and GAI) are able to move for long distances in Arabidopsis and potato (Haywood et al. 2005, Banerjee et al. 2006). GAI RNA is the mRNA for gibberellin acid insensitive (GAI), a DELLA protein of GRAS transcription factors (Pysh et al. 1999). DELLA proteins interact and block the activity of GA-responsive transcription factors (Huang \& Yu 2009). The RNA-protein complexes are subsequently transported into sieve elements through plasmodesmata (Lucas et al. 2009).

Non-coding RNAs (small RNAs as miRNAs, and long RNAs as antisense RNA, dsRNA, and long RNA species) have many roles, functioning as regulators of other mRNAs, at transcriptional 
and post-transcriptional level, and controlling protein ubiquitination and degradation. Several microRNAs has been shown to move through the phloem to exert their activity at distance. MIR172 as well as MIR399, which is induced upon phosphate starvation, is present in small RNA libraries made from phloem exudates indicating that they are part of a long distance signalling network (Chuck \& O'Connor 2010). Phloem specific small RNAs travel to inform the roots of the nutrient status of the shoot, such as miR319 (Zhang et al. 2009) which targets a subset of the TCP family of transcription factors. LOX2 expression may be dependent on TCP4, due to the presence of a promoter motif important for the direct regulation of LOX2 by TCP4 (Schommer et al. 2008).

\section{Conclusions}

The molecular analysis of stress-induced signalling pathways that lead to plant adaptation or to cell death constitutes a major research area in the abiotic stress field. The crossroad between stress adaptation and cell death and the determinant events leading to one or the other direction represent a challenging research area in the next future.

\section{References}

Abuqamar S, Luo H, Laluk K, Mickelbart M V, Mengiste T (2009): Crosstalk between biotic and abiotic stress responses in tomato is mediated by the AIM1 transcription factor. Plant J. 58: 347-360

Balbi V, Devoto A (2008): Jasmonate signalling network in Arabidopsis thaliana: crucial regulatory nodes and new physiological scenarios. New Phytologist 177: 301-318

Baltruschat H, Fodor J, Harrach B D, Niemczyk E, Barna B, Gullner G, Janeczko A, Kogel K-H, Schäfer P, Schwarczinger I, Zuccaro A, Skoczowski A (2008): Salt stress tolerance of barley induced by the root endophyte Piriformospora indi$c a$ is associated with a strong increase in antioxidants. New Phytol. 180: 501-510

Banerjee A K, Chatterjee M, Yu Y, Suh S G, Miller W A, Hannapel D J (2006): Dynamics of a mobile RNA of potato involved in a long-distance signaling pathway. Plant Cell 18: 3443-3457

Beck E H, Fettig S, Knake C, Hartig K, Bhattarai T (2007): Specific and unspecific responses of plants to cold and drought stress. J. Biosci. 32: 501-510

Bender C, Rangaswamy V, Loper J (1999): Polyketide production by plant-associated pseudomonads. Annu. Rev. Phytopathol. 37: 175-196

Blum A (2005): Drought resistance, water-use efficiency, and yield potential—are they compatible, dissonant, or mutually exclusive? Austral. J. Agric. Res. 56: 1159-1168

Bohnert H J, Nelson D F, Jenson R G (1995): Adaptation to environmental stresses. Plant Cell 7: 1099-1111

Boyko A, Hudson D, Bhomkar P, Kathiria P, Kovalchuk I (2006): Increase of homologous recombination frequency in vascular tissue of Arabidopsis plants exposed to salt stress. Plant Cell Physiol. 47: 736-742

Boyko A, Kathiria P, Zemp FJ, Yao Y, Pogribny I, Kovalchuk I (2007): Transgenerational changes in the genome stability and methylation in pathogen-infected plants (Virus-induced plant genome instability). Nucleic Acids Res. 35: 1714-1725

Brini F, Gaxiola R, Berkowitz G, Masmoudi K (2005): Cloning and characterization of a wheat vacuolar cation/proton antiporter and pyrophosphatase proton pump. Plant Physiol. Biochem. 43: 347-354

Brini F, Hanin M, Mezghanni I, Berkowitz G, Masmoudi K. (2007a): Overexpression of wheat $\mathrm{Na}^{+} / \mathrm{H}^{+}$antiporter TNHX1 and $\mathrm{H}^{+}$-pyrophosphatase TV P1 improve salt and drought stress tolerance in Arabidopsis thaliana plants. J. Exp. Bot. 58: 301-308

Brini F, Hanin M, Lumbreras V, Amara I, Khoudi H, Hassairi A, Pagès M, Masmoudi K (2007b): Overexpression of wheat dehydrin DHN-5 enhances tolerance to salt and osmotic stress in Arabidopsis thaliana. Plant Cell Rep. 26: 2017-2026

Chandra Babu R, Shashidhar H E, Lilley J M, Thanh N D, Ray J D, Sadasivam S, Sarkarung S, O’Toole J C, Nguyen HT (2001): Variation in root penetration ability, osmotic adjustment and dehydration tolerance among accessions of rice adapted to rainfed lowland and upland ecosystems. Plant Breed 120: 233-238

Chinnusamy V, Gong Z, Zhu J-K (2008): Abscisic Acid-mediated Epigenetic Processes in Plant Development and Stress Responses. J. Integrative Plant Biol. 50: 1187-1195

Christmann A, Weiler E W, Steudle E, Grill E (2007): A hydraulic signal in root-to-shoot signalling of water shortage. Plant J. $52: 167-174$

Chuck G, O'Connor D (2010): Small RNAs going the distance during plant development. Curr.Op. Plant Biol. 13: 40-45

Cortina C, Culianez-Macia F A (2005): Tomato abiotic stress enhanced tolerance by trehalose biosynthesis. Plant Sci. 169: 75-82

De Domenico S, Tsesmetzis N, Di Sansebastiano G P, Hughes R K, Casey R, Santino A (2007): Subcellular localisation of Medicago truncatula 9/13-hydroperoxide lyase reveals a new localisation pattern and activation mechanism for CYP74C enzymes. BMC Plant Biol. 7: 58

Dodd I C, Egea G, Davies W J (2008): Abscisic acid signalling when soil moisture is heterogeneous: decreased photoperiod sap flow from drying roots limits abscisic acid export to the shoots. Plant Cell Environ. 31: 1263-1274

Franco-Zorrilla J M, Valli A, Todesco M, Mateos I, Puga M I, Rubio-Somoza I, Leyva A, Weigel D, García J A, Paz-Ares J (2007): Target mimicry provides a new mechanism for regulation of microRNA activity. Nat. Genet. 39: 1033-1037

Fricke W, Akhiyarova G, Veselov D, Kudoyarova G (2004): Rapid and tissue-specific changes in $\mathrm{ABA}$ and in growth rate in response to salinity in barley leaves. J. Exp. Bot. 55:11151123

Fujii H, Chinnusamy V, Rodrigues A, Rubio S, Antoni R, Park S Y, Cutler S R, Sheen J, Rodriguez P L, Zhu J K (2009): In vitro reconstitution of an abscisic acid signalling pathway. Nature 462: 660-664

Groppa M D, Benavides M P (2008): Polyamines and abiotic stress: recent advances. Amino Acids 34: 35-45

Hara M, Shinoda Y, Tanaka Y, Kuboi T (2009): DNA binding of citrus dehydrin promoted by zinc ion. Plant Cell Environ. 32: 532-541

Hartung W, Sauter A, Hose E (2002): Abscisic acid in the xylem: where does it come from, where does it go to? J. Exp. Bot. 53: 27-32

Hause B, Schaarschmidt S (2009): The role of jasmonates in mutualistic symbioses between plants and soil-born microorganisms. Phytochem. 70: 1589-1599 
Haywood V, Yu T S, Huang N C, Lucas W J (2005): Phloem long-distance trafficking of GIBBERELLIC ACID-INSENSITIVE RNA regulates leaf development. Plant J. 42: 49-68

Holmstrom K O, Somersalo S, Mandal A, Palva E T, Welin B (2000): Improved tolerance to salinity and low temperature in transgenic tobacco producing glycine betaine. J. Exp. Bot. 51: $177-185$

Hu L, Wang Z, Du H, Huang B (2010): Differential accumulation of dehydrins in response to water stress for hybrid and common bermudagrass genotypes differing in drought tolerance. J. Plant Physiol. 167: 103-109

Huang N-C, Yu T-S (2009): The sequences of Arabidopsis GA-INSENSITIVE RNA constitute the motifs that are necessary and sufficient for RNA long-distance trafficking. Plant J. 59: 921-929

Hughes R K, De Domenico S, Santino A (2009): Plant cytochrome CYP74 family: biochemical features, endocellular localisation, activation mechanism in plant defence and improvements for industrial applications. ChemBioChem. 10: 1122-1133

Hugouvieux V, Kwak J M, Schroeder J I (2001): An mRNA cap binding protein, $\mathrm{ABH} 1$, modulates early abscisic acid signal transduction in Arabidopsis. Cell 106: 477-487

Gfeller A, Liechti R, Farmer E E (2010): Arabidopsis jasmonate signaling pathway. Sci. Signal. 3(109): $\mathrm{cm} 4$.

Javot H, Lauvergeat V, Santoni V, Martin-Laurent F, Güçlü J, Vinh J, Heyes J, Franck KI, Schäffner A R, Bouchez D, Maurel C (2003): Role of a single aquaporin isoform in root water uptake. Plant Cell 15: 509-522

Jiang F, Hartung W (2008): Long-distance signalling of abscisic acid $(A B A)$ : the factors regulating the intensity of the $A B A$ signal. J. Exp. Bot. 59: 37-43

Jiang F, Jeschke W D, Hartung W (2004): Water flows in the parasitic association Rhinantbus minor/Hordeum vulgare. J. Exp. Bot. 55: 2323-2329

Jiménez J A, Alonso-Ramírez A, Nicolás C (2008): Two cDNA clones (FsDhn1 and FsClo1) up-regulated by $\mathrm{ABA}$ are involved in drought responses in Fagus sylvatica L. seeds. J. Plant Physiol. 165: 1798-807

Liu J, Maldonado-Mendoza I, Lopez-Meyer M, Cheung F, Town C D, Harrison M J (2007): Arbuscular mycorrhizal symbiosis is accompanied by local and systemic alterations in gene expression and an increase in disease resistance in the shoots. Plant J. 50: 529-544

Kistner C, Parniske M (2002): Evolution of signal transduction in intracellular symbiosis. Trends Plant Sci. 7: 511-518

Kovacs D, Agoston B, Tompa P (2008): Disordered plant LEA proteins as molecular chaperones. Plant Signal Behav. 3: 710-713

Kovtun Y, Chiu WL, Tena G, Sheen J (2000): Functional analysis of oxidative stress-activated mitogen-activated protein kinase cascade in plants. Proc. Natl. Acad. Sci. USA 97: 2940-2945

Kuromori T, Miyaji T, Yabuuchi H, Shimizu H, Sugimoto E, Kamiya A, Moriyama, Y, Shinozaki K (2010): ABC transporter AtABCG25 is involved in abscisic acid transport and responses. Proc. Natl. Acad. Sci. U.S.A. 107: 2361-2366

Lakatos L, Szittya G, Silhavy D, Burgyán J (2004): Molecular mechanism of RNA silencing suppression mediated by $\mathrm{p} 19$ protein of tombusviruses. EMBO J. 23: 876-884

Lorenzo O, Solano R (2005): Molecular players regulating the jasmonate signalling network. Curr. Opin. Plant Biol. 8: $532-540$

Lough T J, Lucas W J (2006): Integrative plant biology: role of phloem long-distance macromolecular trafficking. Annu. Rev. Plant Biol. 57: 203-232

Lucas W J, Ham B K, Kim J Y (2009): Plasmodesmata - bridging the gap between neighboring plant cells. Trends Cell Biol. 19: 495-503
Luo Z-B, Janz D, Jiang X, Gobel C, Wildhagen H, Tan Y, Rennenberg H, Feussner I, Polle A (2009): Upgrading root physiology for stress tolerance by ectomycorrhizas: insights from metabolite and transcriptional profiling into reprogramming for stress anticipation. Plant Physiol. 151: 1902-1917

Mahouachi, J, Arbona V, Gomez-Cadenas A (2007): Hormonal changes in papaya seedlings subjected to progressive water stress and re-watering. Plant Growth Regul. 53: 43-51

Masle J, Gilmore S R, Farquhar GD (2005): The ERECTA gene regulates plant transpiration efficiency in Arabidopsis. Nature 436: 866-870

Mason H S, DeWald D B, Creelman R A, Mullet J E (1992): Coregulation of soybean vegetative storage protein gene expression by methyl jasmonate and soluble sugars. Plant Physiol. 98: 859-867

Merchan F, de Lorenzo L, Rizzo S G, Niebel A, Manyani H, Frugier F, Sousa C, Crespi M (2007): Identification of regulatory pathways involved in the reacquisition of root growth after salt stress in Medicago truncatula. Plant J. $51: 1-17$

Mlynáriková L, Nap J P, Bisseling T (2007): The SWI/SNF chromatin-remodeling gene AtCHR12 mediates temporary growth arrest in Arabidopsis thaliana upon perceiving environmental stress. Plant J. 51: 874-885

Molinier J, Ries G, Zipfel C, Hohn B (2006): Transgeneration memory of stress in plants. Nature 442: 1046-1049

Moon J, Zhao Y, Dai X, Zhang W, Gray W M, Huq E, Estelle M (2007): A new CULLIN 1 mutant has altered responses to hormones and light in Arabidopsis. Plant Physiol. 143: 684-96

Mouillon J M, Eriksson S K, Harryson P (2008): Mimicking the plant cell interior under water stress by macromolecular crowding: disordered dehydrin proteins are highly resistant to structural collapse. Plant Physiol. 148: 1925-1937

Naumann M, Schüßler A, Bonfante P (2010): The obligate endobacteria of arbuscular mycorrhizal fungi are ancient heritable components related to the Mollicutes. ISME J. [Epub ahead of print].

Oldroyd GE (2007): Plant Science. Nodules and hormones. Science 315: 52-53

Pandey S, Nelson D C, Assmann S M (2009): Two novel GPCR-type $\mathrm{G}$ proteins are abscisic acid receptors in Arabidopsis. Cell 136: 136-148

Pawlowski K, Sirrenberg A (2003): Symbiosis between Frankia and actinorhizal plants: root nodules of non-legumes. Indian J. Exp. Biol. 41: 1165-1183

Pennisi E (2006): Fungi Helps Grass Beat the Heat. Science 302: 774-775

Perazzolli M, Romero-Puertas M C, Delledonne M (2006): Modulation of nitric oxide bioactivity by plant haemoglobins. J. Exp. Bot. 57: 479-488

Plaut Z, Butow B J, Blumenthal C S, Wrigley C W (2004): Transport of dry matter into developing wheat kernels and its contribution to grain yield under post-anthesis water deficit and elevated temperature. Field Crops Res. 86: 185-198

Pysh L D, Wysocka-Diller J W, Camilleri C, Bouchez D, Benfey P N (1999): The GRAS gene family in Arabidopsis: sequence characterization and basic expression analysis of the SCARECROW-LIKE genes. Plant J. 18: 111-119

Razem F A, Baron K, Hill R D (2006): Turning on gibberellin and abscisic acid signaling. Curr. Opin. Plant Biol. 9: 454-459

Sauter A, Hartung W (2000): Radial transport of abscisic acid conjugates in maize roots: its implication for long distance stress signals. J. Exp. Bot. 51: 929-935

Sauter A, Davies W J, Hartung W (2001): The long-distance abscisic acid signal in the droughted plant: the fate of the hormone on its way from root to shoot. J. Exp. Bot. 52: 1991-1997 
Schachtman D P, Goodger J Q D (2008): Chemical root to shoot signalling under drought. Trends Plant Sci. 13: 281-287

Schommer C, Palatnik J, Aggarwal P, Chételat A, Cubas P, Farmer E E, Nath U, Weigel D (2008): Control of jasmonate biosynthesis and senescence by miR319 targets. PLoS Biol. 6: e230

Seki M, Umezawa T, Urano K, Shinozaki K (2007): Regulatory metabolic networks in drought stress responses. Curr. Opin. Plant Biol. 10: 296-302

Schüssler A, Martin H, Cohen D, Fitz M, Wipf D (2006): Characterization of a carbohydrate transporter from symbiotic glomeromycotan fungi. Nature 444: 933-6

Simpson G G, Dijkwel PP, Quesada V, Henderson I, Dean C (2003): FY is an RNA $3^{\prime}$ end-processing factor that interacts with FCA to control the Arabidopsis floral transition. Cell 113: $777-787$

Smagghe B J, Hoy J A, Percifield R, Kundu S, Hargrove MS, Sarath G, Hilbert JL, Watts RA, Dennis ES, Peacock WJ, Dewilde S, Moens L, Blouin GC, Olson JS, Appleby CA (2009): Review: correlations between oxygen affinity and sequence classifications of plant hemoglobins. Biopolymers 1: 1083-96

Stoll M, Loveys B, Dry P (2000): Hormonal changes induced by partial rootzone drying of irrigated grapevine. J. Exp. Bot. 51: 1627-1634

Taghavi S, van der Lelie D, Hoffman A, Zhang Y-B, Walla M D, Vangronsveld J, Newman L, Monchy S (2010) Genome sequence of the plant growth promoting endophytic bacterium Enterobacter sp. 638. PLoS Genet. 6: e1000943

Tardieu F, Tuberosa R (2010): Dissection and modelling of abiotic stress tolerance in plants. Curr. Opin. Plant Biol. 13: 206-212

Thomas H, Howarth C J (2000): Five ways to stay green. J. Exp. Bot. 51: 329-337
Tiryaki I, Staswick P E (2002): An Arabidopsis mutant defective in jasmonate response is allelic to the auxin-signaling mutant axr1. Plant Physiol. 130: 887-894

Van der Ent S, Van Hulten M, Pozo M J, Czechowski T, Udvardi M K, Pieterse C M, Ton J (2009): Priming of plant innate immunity by rhizobacteria and beta-aminobutyric acid: differences and similarities in regulation. New Phytol. 183: 419-431

Weiler E W, Kutchan T M, Gorba T, Brodschelm W, Niesel U, Bublitz F (1994): The Pseudomonas phytotoxin coronatine mimics octadecanoid signalling molecules of higher plants. FEBS Lett. 345: 9-13

White J F, Torres M S (2010): Is plant endophyte-mediated defensive mutualism the result of oxidative stress protection? Physiol. Plant. 138: 440-446

Xoconostle-Cázares B, Xiang Y, Ruiz-Medrano R, Wang HL, Monzer J, Yoo BC, McFarland KC, Franceschi VR, Lucas WJ (1999): Plant paralog to viral movement protein that potentiates transport of mRNA into the phloem. Science 283: $94-98$

Yang J, Kloepper J W, Ryu C M (2009): Rhizosphere bacteria help plants tolerate abiotic stress. Trends Plant Sci. 14: 1-4

Yin P, Fan H, Hao Q, Yuan X, Wu D, Pang Y, Yan C, Li W, Wang J, Yan N (2009): Structural insights into the mechanism of abscisic acid signaling by PYL proteins. Proc. Natl. Acad. Sci. U.S.A. 16: 1230-1236

Zhang J, Subramanian S, Zhang Y, Yu O (2007): Flavone synthases from Medicago truncatula are flavanone-2-hydroxylases and are important for nodulation. Plant Physiol. 144: 741 751

Zhang S, Sun L, Kragler F (2009): The phloem-delivered RNA pool contains small noncoding RNAs and interferes with translation. Plant Physiol. 150: 378-387

\title{
Molekularni mehanizmi odgovora biljaka na abiotički stres
}

\author{
Palmiro Poltronijeri $\cdot$ Stefanija Bonsenja $\cdot$ Stefanija De Domeniko $\cdot$ Anđelo Santino
}

ISPA-CNR, Institut za prehrambenu tehnologiju, Via Monteroni 73100 Leće, Italija

Izvod: Poboljšane sorte ratarskih useva su potrebne za održavanje zaliha hrane, borbu protiv klimatskih promena, nedostatka vode, povećanja temperature i visoke varijabilnost padavina. Varijabilnost suše i porast zaslanjenosti zemljišta imaju nepovoljan uticaj na rast biljaka, a abiotički stres ozbiljno ugrožava održivu poljoprivrednu proizvodnju. Kako bi se prevazišao uticaj abiotičkog stresa, javlja se potreba za novim, tolerantnim sortama i tehnikama oplemenjivanja uz asistiranu selekciju. Neophodno je dublje razumevanje mehanizama koji reaguju na stres i održavaju otpornost na stres. Ovde je prikazan pregled nekoliko mehanizama koji međusobno deluju pri odgovoru na stres. Danas se bolje razumeju lokalizovana sinteza biljnih hormona, sekundarni mesendžeri i lokalni efektori odgovora na abiotički stres i opstanak, kao i signalni putevi regulisani biljnim hormonima. U žiži mnogih novijih istraživanja su metaboličke mreže u odgovoru na sušu, signalizacije na velika rastojanja i komunikacija između biljnih organa pripremljenih za ekspresiju gena protiv abiotičkog stresa osobenu za pojedina tkiva.

Ključne reči: abscisinska kiselina (ABA), jasmonat (JA), osmotsko prilagođavanje (OP), transkripcioni faktor (TF) 